\title{
Type-II Core/Shell Nanowire Heterostructures and Their Photovoltaic Applications
}

\author{
Yiyan Cao, Zhiming Wu*, Jianchao Ni, Waseem. A. Bhutto, Jing Li, Shuping Li, Kai Huang \\ Junyong Kang*
}

(Received 30 August 2012; accepted 3 September 2012; published online 25 September 2012.)

\begin{abstract}
Nanowire-based photovoltaic devices have the advantages over planar devices in light absorption and charge transport and collection. Recently, a new strategy relying on type-II band alignment has been proposed to facilitate efficient charge separation in core/shell nanowire solar cells. This paper reviews the type-II heterojunction solar cells based on core/shell nanowire arrays, and specifically focuses on the progress of theoretical design and fabrication of type-II $\mathrm{ZnO} / \mathrm{ZnSe}$ core/shell nanowire-based solar cells. A strong photoresponse associated with the type-II interfacial transition exhibits a threshold of $1.6 \mathrm{eV}$, which demonstrates the feasibility and great potential for exploring all-inorganic versions of type-II heterojunction solar cells using wide bandgap semiconductors. Future prospects in this area are also outlooked.
\end{abstract}

Keywords: Type-II heterostructures; Core/shell nanowire solar cell; $\mathrm{ZnO} / \mathrm{ZnSe}$

Citation: Yiyan Cao, Zhiming Wu, Jianchao Ni, Waseem. A. Bhutto, Jing Li, Shuping Li, Kai Huang and Junyong Kang, "Type-II Core/Shell Nanowire Heterostructures and Their Photovoltaic Applications", Nano-Micro Lett. 4 (3), 135-141 (2012). http://dx.doi.org/10.3786/nml.v4i3.p135-141

\section{Introduction}

In recent years, global energy issues and rapidly growing environmental concerns have become more and more imperative, and significant progresses have been made in the development of renewable energy technologies, such as solar cells, fuel cells, and biofuels. Among them, solar cell is deemed as the most potential approach because of the abundant, inexhaustible and universally available energy resources. Nowadays, it is widespreadly used in aerospace, however, the most expected application in power stations is still limited because of the high cost and the shortage of electricity storage technology. To change present status, innovations are obviously needed to lower cost and improve the conversion efficiency.

Conventional solar cells basically operate on the principle of p-n junction formed by joining p- and n-type semiconductors. An analysis based on the ShockleyQueisser detailed balance theory shows that the semi- conductor with bandgap of about $1.45 \mathrm{eV}$ is preferable for this kind of single-junction solar cell [1]. As a result, the narrow-band gap semiconductor materials, such as $\mathrm{Si}(1.12 \mathrm{eV})$ [2], GaAs (1.43 eV) [3,4], $\mathrm{CuInS}_{2}(1.53 \mathrm{eV})$ [5], and CdTe (1.45 eV) [6-9], are widely used and studied in solar cells. To date, the maximal efficiencies for Si and GaAs solar cell have reached up to $24.7 \%$ [10] and $28.3 \%$ [11], respectively, which are almost close to their theoretical limitations. To further improve conversion efficiency, a conceptually straightforward way is to use a stack of cascaded multiple p-n junctions with bandgaps better matching to solar spectrum, such as GaAs-based multi-junction solar cell [12]. Record conversion efficiencies above $40 \%$ have been reported for multi-junction cells using concentrated sunlight [13-15]. Although substantial advances have been made in efficiency, the cost of power generation for solar cell is still higher than that for the conventional resource, such as coal, gas or oil.

Currently, a new generation of nanowire-based so-

Fujian Key Laboratory of Semiconductor Materials and Applications, Department of Physics, Xiamen University, Xiamen 361005, China *Corresponding author. E-mail: zmwu@xmu.edu.cn, jykang@xmu.edu.cn 
lar cells has been receiving enormous attention because of their potential advantages in efficiency and cost. Compared with planar structure, nanowires can effectively enhance light absorption by suppressing light reflectance and increasing light coupling [16,17]. These advantages promote the development of nanowire-based solar cells. In particular, coaxial nanowire structure is more beneficial to collect carriers because of the novel mechanism of radial charge separation [18-20]. In these nano-architecture photovoltaic devices, two types of structures, namely, p-n junction $[18,21]$ and type-II heterojunction [20], are commonly employed. For instance, B. Z. Tian et al. reported the realization of p-type/intrinsic/n-type (p-i-n) coaxial silicon nanowire solar cell with a conversion efficiency of up to $3.4 \%$ under one sun [22]. As for type-II heterojunction, it can function similarly as a p-n junction, but without having to deliberately dope the nanowire. In addition, type-II heterojunction can also substantially reduce bandgap indirectly in spatial to efficiently absorb the sun light, although both materials constituting heterostructure have wider bandgaps $[20,23]$. Such heterojunctions have been intensively investigated for photovoltaic applications, including dye-sensitized solar cell (DSSC) [24,25], quantum dot-sensitized solar cell (QDSSC) [12,26], core/shell nanowire solar cells [27,28], and so on [29-35]. Compared with DSSC or QDSSC, core/shell nanowire solar cells have the advantages in light absorption, current transportation and charge separation [18-20,36]. In this paper, we will primary focus on the achievements, challenges, and prospects of typeII core/shell nanowire arrays (NWAs), with the emphasis on $\mathrm{ZnO} / \mathrm{ZnSe}$ coaxial nanowire solar cell.

\section{Theoretical design of type-II het- erostructures}

Heterostructures are generally formed by bringing two different semiconductors into physical contact, which can be typically classified as type-I (straddling gap), type-II (staggered gap) and type-III (broken gap) depending on the alignment of energy bands. The former two types are more commonly used in practical heterostructure devices. For type-I heterostructure, both the conduction and valence band edges of the semiconductor $\left(\operatorname{sem}_{1}\right)$ with the narrower bandgap are located within the band of another semiconductor $\left(\mathrm{sem}_{2}\right)$, as shown in Fig. 1(a), which is advantageous for electrons and holes to simultaneously accumulate in the $\operatorname{sem}_{1}$, and thus enhance the carrier recombination. This band structure is often used to fabricate lasers, light emitting diodes, etc. As for type-II heterostructure, a staggered band offset is formed at interface, and the lowest energy positions for electrons and holes are located in different materials, respectively. This means that type-II het- erostructures can carry out charge separation, and is potential for photovoltaic applications [37].

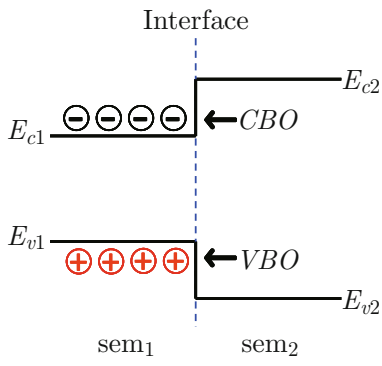

(a)

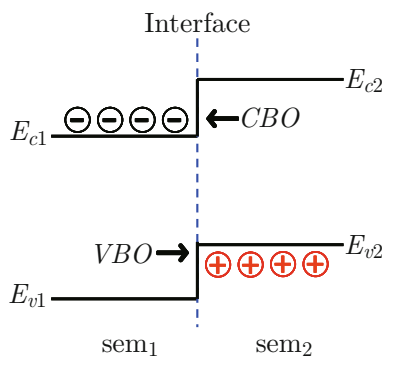

(b)
Fig. 1 Schematic energy band diagram for type-I (a), and type-II (b) heterostructures.

There have been numerous attempts and models to predict and calculate the electronic structures and properties of type-II heterostructures [20,23, 38-40]. To date, the reported type-II heterostructures are mainly based on II-VI and III-V binary semiconductors, such as $\mathrm{ZnO} / \mathrm{ZnS}$ [41], $\mathrm{ZnO} / \mathrm{ZnSe}$ [42], $\mathrm{ZnO} / \mathrm{ZnTe}$ [23], $\mathrm{CdSe} / \mathrm{CdTe}$ [43], and GaN/GaP [20], as shown in Table 1. Among them, $\mathrm{ZnO}$-based heterostructures attracted more attentions due to its abundant resources and facilitating growth [44]. For instance, J. Schrier et al. have theoretically analyzed the electronic structures and optical properties of $\mathrm{ZnO} / \mathrm{ZnS}$ and $\mathrm{ZnO} / \mathrm{ZnTe}$ [23], and revealed low absorption limitation of $2.07 \mathrm{eV}$ and 1.17 $\mathrm{eV}$, respectively. The simulation results for other typeII heterostructures are also listed in Table 1. It can be seen that there are some deviation between the effective bandgap and the optimal bandgap of $1.45 \mathrm{eV}$ for solar cell.

Table 1 Type-II heterostructure materials and effective bandgap

\begin{tabular}{cccc}
\hline Heterostructures & $\begin{array}{c}\text { Location of valence } \\
\text { band maximum }\end{array}$ & $\begin{array}{c}\text { Effective } \\
\text { bandgap }(\mathrm{eV})\end{array}$ & Reference \\
\hline $\mathrm{ZnO} / \mathrm{ZnS}$ & $\mathrm{ZnS}$ & 2.07 & {$[23]$} \\
$\mathrm{ZnO} / \mathrm{ZnSe}$ & $\mathrm{ZnSe}$ & 1.84 & {$[42]$} \\
$\mathrm{ZnO} / \mathrm{ZnTe}$ & $\mathrm{ZnTe}$ & 1.17 & {$[23]$} \\
$\mathrm{ZnO} / \mathrm{CdS}$ & $\mathrm{CdS}$ & 2.17 & {$[45]$} \\
$\mathrm{ZnO} / \mathrm{CdSe}$ & $\mathrm{CdSe}$ & 1.73 & {$[46]$} \\
$\mathrm{ZnSe} / \mathrm{ZnTe}$ & $\mathrm{ZnTe}$ & 2.07 & {$[47]$} \\
$\mathrm{CdSe} / \mathrm{CdTe}$ & $\mathrm{CdTe}$ & 1.16 & {$[43]$} \\
$\mathrm{CdS} / \mathrm{ZnSe}$ & $\mathrm{ZnSe}$ & 2.05 & {$[48]$} \\
$\mathrm{CdSe} / \mathrm{ZnTe}$ & $\mathrm{ZnTe}$ & 1.07 & {$[49]$} \\
$\mathrm{GaN} / \mathrm{GaP}$ & $\mathrm{GaP}$ & 0.87 & {$[20]$} \\
\hline
\end{tabular}

Recently, we designed two kinds of type-II heterostructures of $\mathrm{ZnO}$ (wurtzite)/ZnSe (wurtzite) and $\mathrm{ZnO}$ (wurtzite)/ZnSe (zinc-blende) by first-principle calculations [50], as shown in Fig. 2. It was found that the $\mathrm{ZnO}$ (wurtzite)/ZnSe (wurtzite) heterostructure is preferable to solar cell applications because 
of the lower effective bandgap of $1.51 \mathrm{eV}$, which is almost close to the optimal bandgap of solar cell. Furthermore, the electrons and holes can be high effectively separated at the interface of $\mathrm{ZnO}$ (wurtzite)/ZnSe (wurtzite) heterostructure due to the strong misfit stress field. An optimal structure of $\mathrm{ZnO}$ (wurtzite)/ZnSe (wurtzite)/ZnSe (zinc-blende) was proposed to realize a solar cell with near-infrared response. Figure 3 shows the spatial distributions of partial charge densities, revealing that the strained zinc-blende ZnSe layer can high efficiently transport current from the wurtzite ZnSe layer.

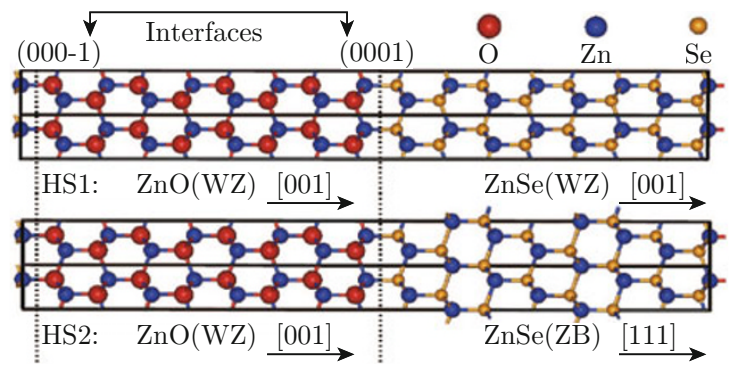

Fig. 2 Structures of $\mathrm{ZnO}$ (wurtzite)/ZnSe (wurtzite) and $\mathrm{ZnO}$ (wurtzite)/ZnSe (zinc-blende) heterostructures.

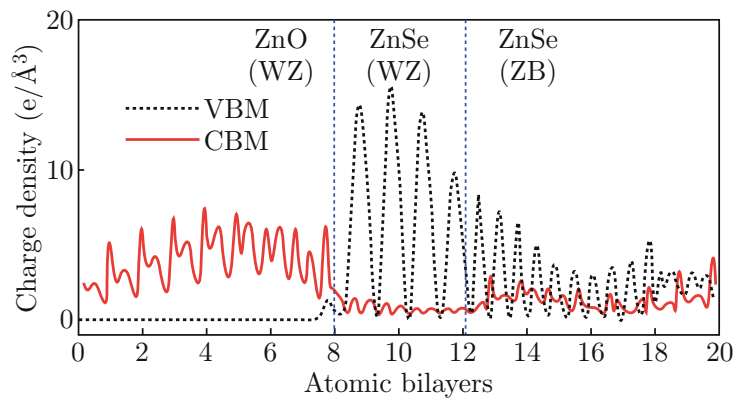

Fig. 3 Partial charge densities of VBM (dash line) and CBM (solid line) for $\mathrm{ZnO}$ (wurtzite)/ZnSe (wurtzite)/ZnSe (zinc-blende) heterostructure.

Considering the actually practical structure, we also design a $\mathrm{ZnO} / \mathrm{ZnSe}$ core/shell structure with 240 atoms containing two layers of $\mathrm{ZnO}$ in the core and two layers of $\mathrm{ZnSe}$ in the shell. The wire model orientates along [0001] direction enclosed by six $\{1 \overline{1} 00\}$ facets, and all the dangling bonds on surface were saturated by hydrogen atoms. The relaxed ZnSe layers near the interface trend to be of the same lattice constant as the inner $\mathrm{ZnO}$, as shown in Fig. 4, which means that a coherent layer is easy to form in the $\mathrm{ZnO} / \mathrm{ZnSe}$ coaxial nanowires, and above mentioned heterostructure of $\mathrm{ZnO}$ (wurtzite)/ZnSe (wurtzite) can be fabricated. Figure 5 shows the charge distributions (the squares of the wavefunctions) for the conduction band minimum $(\mathrm{CBM})$ and valence band maximum (VBM). The electron is largely localized in the $\mathrm{ZnO}$ core, whereas the hole is confined to the ZnSe shell, revealing the high separation efficiency and feasibility of photovoltaic application for $\mathrm{ZnO} / \mathrm{ZnSe}$ coaxial nanowire.

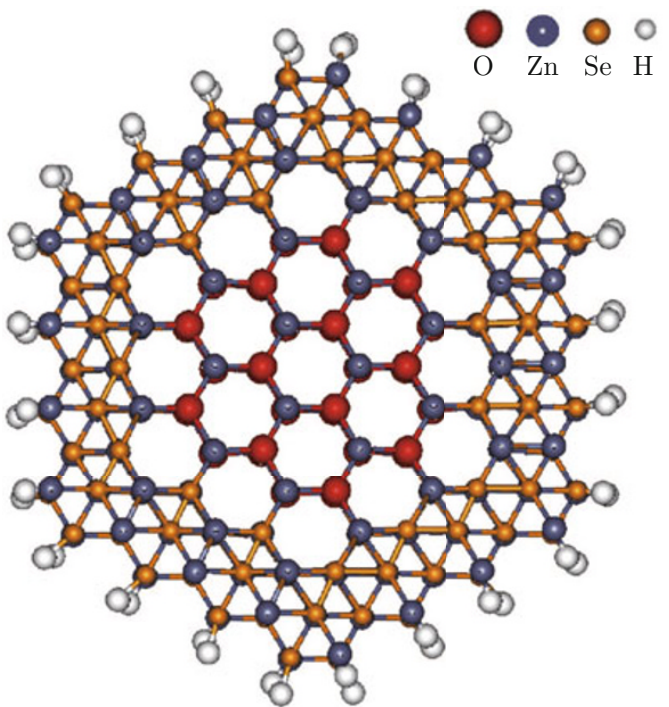

Fig. 4 Atomic structure of $\mathrm{ZnO} / \mathrm{ZnSe}$ core/shell heterostructure in the (0001) plane with hydrogenated facets.
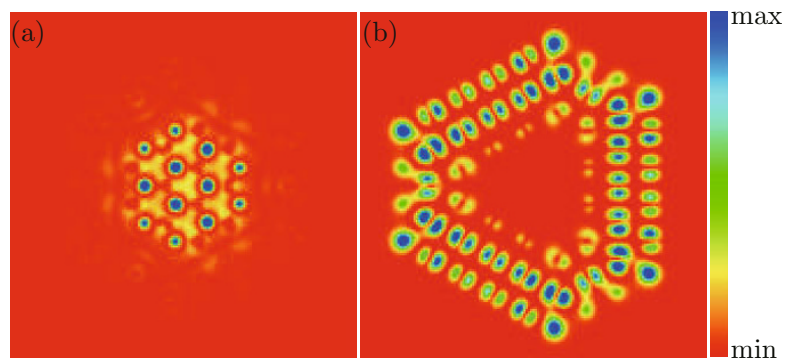

Fig. 5 Cross-section views of charge distributions of $\mathrm{ZnO} / \mathrm{ZnSe}$ core/shell heterostructure: (a) the CBM electron state, and (b) the VBM hole state.

\section{Fabrication of type-II core/shell nanowire-based solar cells}

Recently, type-II heterostructures have often been used to construct nano-photovoltaic devices. The two most common types are quantum dot-sensitized solar cells (QDSSCs) [12] and coaxial nanowire solar cells [51]. Figure 6 shows the schematic diagram of quantum dot-sensitized solar cells and coaxial solar cells based on well-aligned nanowires. The essential differences between them are the inner quantum structure materials. The QDSSCs are formed by coating quantum dots (QDs) onto well-aligned NWAs, and there is lack of a continuous current path due to the isolation of QDs. As a result, an additional liquid electrolyte or hole conductor is needed to connect anode. As for the coaxial nanowire solar cells, the inner nanowire is fully surrounded by another semiconductor material which can directly be used as the current path to anode. 

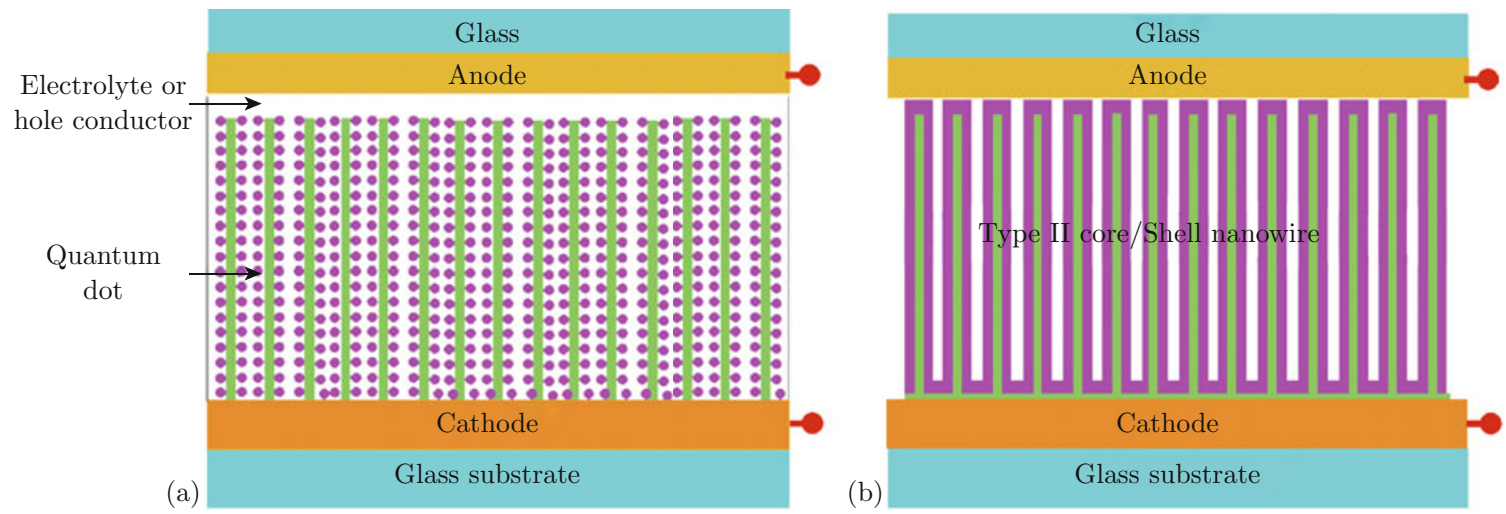

Fig. 6 Schematics of (a) type-II nanowires-based quantum dot-sensitized solar cells, and (b) type-II core/shell nanowiresbased solar cells.

When light incidents upon solar cells, photons captured by the QDs or coaxial nanowire generate electron-hole pairs which are rapidly separated at the type-II heterojunction interface. Electrons are injected into inner nanowires and transport out to the cathode, whereas holes are injected into a hole conductor or electrolyte (QDSSCs) or the shell of coaxial nanowires (coaxial nanowire solar cells) and transport out to the anode. Compared with QDSSCs, coaxial nanowire solar cells provide a larger type-II interfacial area, which is in favor of higher charge separation efficiency. In addition, the longitudinal size of coaxial nanowire more matches with solar light wavelength, resulting in a higher light absorption efficiency. Furthermore, the recent theoretical studies predicted that type-II coaxial nanowire can have three light absorption regions, including the nearband-edge absorption of the core and shell layer, and the interfacial transition absorption [51]. Generally, interfacial transition locates in infrared regions. Therefore, type-II coaxial solar cells, acting as multi-junction solar cells, are potential to be full-spectrum cells by the modulation of composition, structure, and interface.

Many studies have been made from worldwide research groups in type-II coaxial nanowire growth and photovoltaic applications [52-58]. Zhang's group fabricated the vertically aligned $\mathrm{ZnO} / \mathrm{ZnSe}$ and $\mathrm{ZnO} / \mathrm{ZnS}$ core/shell NWAs by CVD method $[42,59]$, and investigated the photovoltaic effect of the $\mathrm{ZnO} / \mathrm{ZnS}$ NWA. Lee's group synthesized $\mathrm{ZnO} / \mathrm{ZnSe}$ heterostructure NWAs with different morphologies through solutionbased surface modifications [54,55]. Lim's group also grew $\mathrm{ZnO} / \mathrm{ZnSe}$ core/shell NWAs by successive ionic layer adsorption and reaction method, and develops a photovoltatic device with an overall conversion efficiency of $1.37 \%$ [56]. Chang's group synthesized $\mathrm{ZnO} / \mathrm{ZnTe}$ core/shell NWAs on an a-plane sapphire substrate by CVD and metal-organic chemical deposition [58]. Despite of so many studies, the predicted longer wavelength transitions at type-II interface has not been convincingly observed. Excitingly,
Kang's group reported the achivement of well-aligned $\mathrm{ZnO} / \mathrm{ZnSe}$ coaxial nanowires with a transition layer of wurtzite $\mathrm{ZnSe}$ between the wurtzite $\mathrm{ZnO}$ core and the zinc-blende ZnSe, and for the first time observed the interfacial transition extending the photoresponse to a threshold much below the bandgap of either component (3.3 and $2.7 \mathrm{eV}$, respectively) at $1.6 \mathrm{eV}$ [51]. Figure 7 shows the transmission spectra of $\mathrm{ZnO}$ and $\mathrm{ZnO} / \mathrm{ZnSe}$ core/shell NWA and their derivative curves, respectively. As predicted by theory, three absorption regions are observed with the peaks around 3.2, 2.7, and $1.6 \mathrm{eV}$, which are attributed to the near-band-edge absorption of $\mathrm{ZnO}$ and $\mathrm{ZnSe}$, and the interfacial transition absorption, respectively. Figure 8 shows the photovoltaic device based on such a $\mathrm{ZnO} / \mathrm{ZnSe}$ core/shell NWA. The large open-circuit voltage of $0.7 \mathrm{~V}$ and the external quantum efficiency of $\sim 4 \%$ at $1.9 \mathrm{eV}$ and $9.5 \%$ at $3 \mathrm{eV}$ (shown in Fig. 8), are among the highest reported value for the nanowire-based solar cells. These

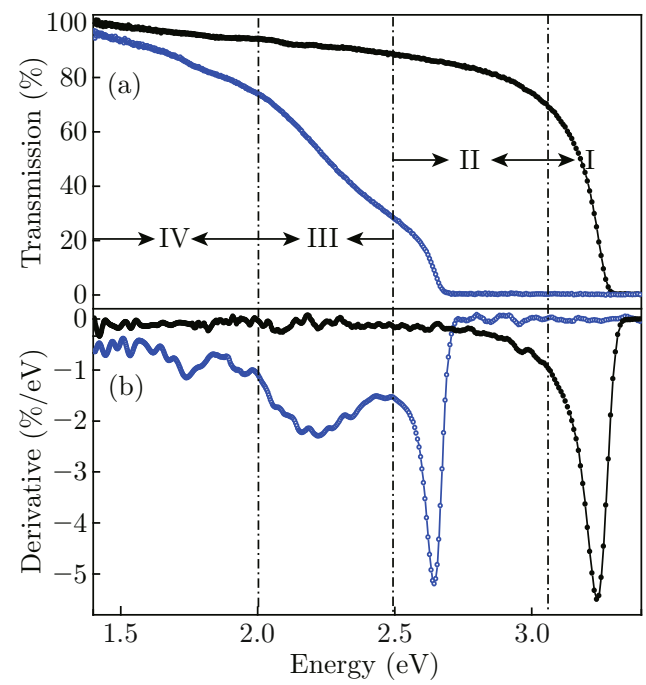

Fig. 7 (a) The transmission spectra of $\mathrm{ZnO}$ and $\mathrm{ZnO} / \mathrm{ZnSe}$ core/shell nanowire array; (b) Derivative curves of the transmission spectra (a). 

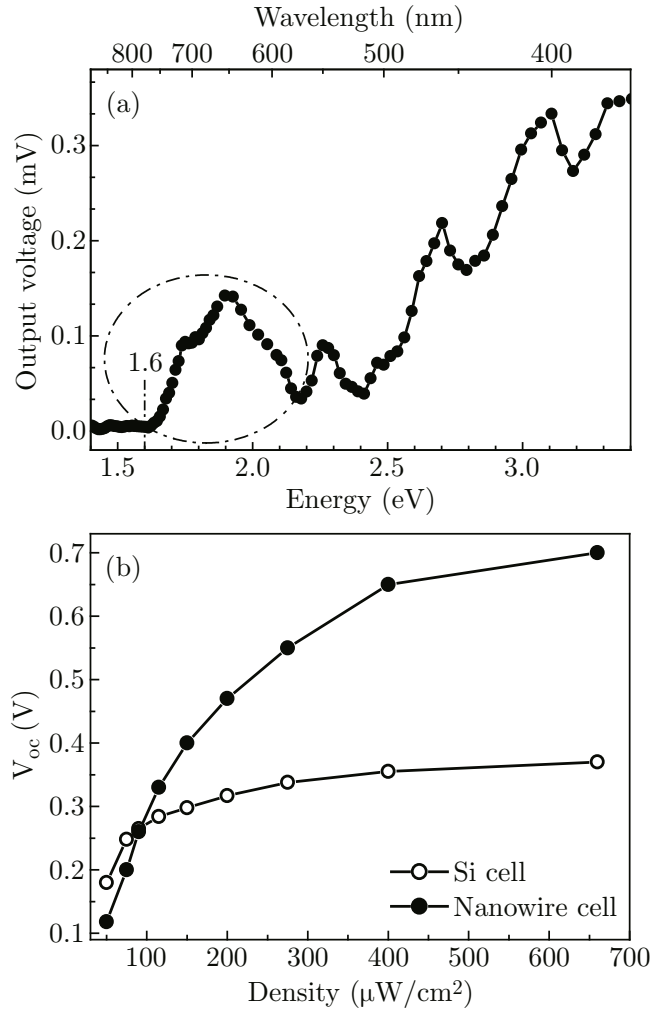

Fig. 8 (a) EQE of a photovoltaic device based on $\mathrm{ZnO} / \mathrm{ZnSe}$ core/shell NWAs; (b) Open-circuit voltage of the NWA cell and Si cell radiated by a He-Ne laser with different power densities.

results represent a major advance towards the realization of all-inorganic type-II heterojunction photovoltaic devices.

\section{Conclusion and perspective}

In this paper, we gave a brief overview of the theoretical design of type-II heterojunction and recent developments in type-II heterojunction solar cells based on core/shell NWAs, with an emphasis on $\mathrm{ZnO} / \mathrm{ZnSe}$ coaxial nanowire solar cell. In view of its high theoretical conversion efficiency, simple fabrication process, and low cost, type-II coaxial nanowire solar cells have a great potential to lead a new generation of photovoltaic applications. Unfortunately, as for now, the efficiency of this kind of device is lower than that of other classes of solar cells. Issues to be considered include the high contact resistance between coaxial nanowires and electrodes, surface recombination problems associated with the high surface area of the nanowires, and the mismatching between the absorption spectrum and the solar spectrum. Further efforts, such as improvement in Ohmic contact, structural optimization [60], and device integration, are needed for this new technique to be competitive with the other more mature ones.

\section{Acknowledgments}

The work was supported by "973" Program (No. 2012CB619301 and 2011CB925600), the National Natural Science Foundations of China (No. 61227009, $61106008,61106118,90921002$, and 60827004), the Natural Science Foundations of Fujian Province, and the fundamental research funds for the central universities (No. 2011121042 and 2011121026).

\section{References}

[1] W. Shockley and H. J. Queisser, J. Appl. Phys. 32, 510 (1961). http://dx.doi.org/10.1063/1.1736034

[2] D. M. Chapin, C. S. Fuller and G. L. Pearson, J. Appl. Phys. 25, 676 (1954). http://dx.doi.org/10.1063/1. 1721711

[3] M. Yamaguchi, A. Yamamoto, and Y. Itoh, J. Appl. Phys. 59, 1751 (1986). http://dx.doi.org/10.1063/ 1.336439

[4] C. Algora, E. Ortiz, I. Rey-Stolle, V. Diaz, R. Pena, V. M. Andreev, V. P. Khvostikov and V. D. Rumyantsev, IEEE Trans. Elec. Dev. 48, 840 (2001). http:// dx.doi.org/10.1109/16.918225

[5] J. J. Loferski, J. Appl. Phys. 27, 777 (1956). http:// dx.doi.org/10.1063/1.1722483

[6] D. A. Cusano, Solid-State Electronics 6, 217 (1963). http://dx.doi.org/10.1016/0038-1101(63) 90078-9

[7] P. V. Meyers, Solar Cell 23, 59 (1988). http://dx. doi.org/10.1016/0379-6787 (88) 90007-5

[8] L. D. Partain (Ed.), Solar Cells and Their Applications, Wiley, 1995.

[9] M. A. Green, Solar Cells: Operating Principles, Technology and Systems Applications, Prentice-Hall, 1992.

[10] J. Zhao, A. Wang and M. A. Green, Prog. Photovoltaics: Res. Appl. 7, 471 (1999). http://dx. doi.org/10.1002/(SICI) 1099-159X (199911/12) 7 : 6<471: : AID-PIP298>3. 0.CO;2-7

[11] M. A. Green, K. Emery, Y. Hishikawa, W. Warta and E. D. Dunlop, Progress in Photovoltaics: Research and Applications 20, 12 (2012). http://dx.doi.org/10. 1002/pip. 2163

[12] K. S. Leschkies, R. Divakar, J. Basu, E. E. Pommer, J. E. Boercker, C. B. Carter, U. R. Kortshagen, D. J. Norris, and E. S. Aydil, Nano Lett. 7, 1793 (2007). http://dx.doi.org/10.1021/n1070430o

[13] W. Guter, J. Schone, S. P. Philipps, M. Steiner, G. Siefer, A. Wekkeli, E. Welser, E. Oliva, A. W. Bett and F. Dimroth, Appl. Phys. Lett. 94, 223504 (2009). http://dx.doi.org/10.1063/1.3148341

[14] M. A. Green, K. Emery, Y. Hishikawa, and W. Warta, Prog. Photovoltaics: Res. Appl. 17, 320 (2009). http://dx.doi.org/10.1002/pip.911

[15] J. F. Geisz, D. J. Friedman, J. S. Ward, A. Duda, W. J. Olavarria, T. E. Moriarty, J. T. Kiehl, M. J. Romero, A. G. Norman, and K. M. Jones, Appl. 
Phys. Lett. 93, 123505 (2008). http://dx.doi.org/ 10.1063/1.2988497

[16] L. Hu and G. Chen, Nano Lett. 7, 3249 (2007). http:// dx.doi.org/10.1021/nl071018b

[17] Y. J. Lee, D. S. Ruby, D. W. Peters, B. B. McKenzie and J. W. P. Hsu, Nano Lett. 8, 1501 (2008). http:// dx.doi.org/10.1021/n1080659j

[18] B. M. Kayes, H. A. Atwater, and N. S. Lewis, J. Appl. Phys. 97, 114302 (2005). http://dx.doi.org/ 10.1063/1.1901835

[19] A. Nduwimana and X. Q. Wang, Nano Lett. 9, 283 (2009). http://dx.doi.org/10.1021/nl802907d

[20] Y. Zhang, L. Wang and A. Mascarenhas, Nano Lett. 7, 1264 (2007). http://dx.doi.org/10.1021/n1070174f

[21] Y. F. Zhang, Y. F. Wang, N. Chen, Y. Y. Wang, Y. Z. Zhang, Z. H. Zhou and L. M. Wei, Nano-Micro Lett. 2, 22-25 (2010). http://dx.doi.org/10.5101/ $\mathrm{nml} \cdot \mathrm{v} 2 \mathrm{i} 1 \cdot \mathrm{p} 22-25$

[22] B. Z. Tian, X. L. Zheng, T. J. Kempa, Y. Fang, N. F $\mathrm{Yu}$, G. H. Yu, J. L. Huang and C. M. Lieber, Nature 449, 885 (2007). http://dx.doi.org/10.1038/ nature06181

[23] J. Schrier, D. O. Demchenko and L. W. Wang, Nano Lett. 7, 2377 (2007). http://dx.doi.org/10.1021/ nl071027k

[24] E. J. W. Crossland, M. Nedelcu, C. Ducati, S. Ludwigs, M. A. Hillmyer, U. Steiner, and H. J. Snaith, Nano Lett. 9, 2813 (2009). http://dx.doi.org/10. $1021 / \mathrm{nl} 803174 \mathrm{p}$

[25] E. L. Tae, S. H. Lee, J. K. Lee, S. S. Yoo, E. J. Kang and K. B. Yoon, J. Phys. Chem. B 109, 22513 (2005). http://dx.doi.org/10.1021/jp0537411

[26] H. J. Lee, M. K. Wang, P. Chen, D. R. Gamelin, S. M. Zakeeruddish, M. Gratzel and Md. K. Nazeeruddin, Nano Lett. 9, 4221 (2009). http://dx.doi.org/ 10.1021/n1902438d

[27] S. A. Ivanov, A. Piryatinski, J. Nanda, S. Tretiak, K. R. Zavadil, W. O. Wallace, D. Werder and V. I. Klimov, J. Am. Chem. Soc. 129, 11708 (2007). http:// dx.doi.org/10.1021/ja068351m

[28] H. Z. Zhong, Y. Zhou, Y. Yang, C. Yang, and Y. F. Li, J. Phys. Chem. C 111, 6538 (2007). http://dx.doi. org/10.1021/jp0709407

[29] Y. Yu, P. V. Kamat and M. Kuno, Adv. Funct. Mater. 20, 1464 (2010). http://dx.doi.org/10.1002/adfm. 200902372

[30] Y. Kang, N.-G. Park, and D. Kim, Appl. Phys. Lett. 86, 113101 (2005). http://dx.doi.org/10.1063/1. 1883319

[31] B. R. Saunders and M. L. Turner, Adv. Colloid Interface Sci. 138, 1 (2008). http://dx.doi.org/10.1016/ j.cis. 2007.09.001

[32] S. Dayal, N. Kopidakis, D. C. Olson, D. S. Ginley and G. Rumbles, Nano Lett. 10, 239 (2010). http://dx. doi.org/10.1021/n1903406s

[33] A. J. Nozik, M. C. Beard, J. M. Luther, M. Law, R. J. Ellingson, and J. C. Johnson, Chem. Rev. 110, 6873 (2010). http://dx.doi.org/10.1021/cr900289f
[34] P. V. Kamat, J. Phys. Chem. C 112, 18737 (2008). http://dx.doi.org/10.1021/jp806791s

[35] K. Sun, A. Kargar, N. Park, K. N. Madsen, P. W. Naughton, T. Bright, Y. Jing, and D. L. Wang, IEEE Journal of Selected Topics in Quantum Electronics (17), 1033 (2011). http://dx.doi.org/10.1109/ jstqe. 2010.2090342

[36] H. W. Wei, L. Wang, Z. P. Li, S. Q. Ni, and Q. Q. Zhao, Nano-Micro Lett. 3, 6 (2011). http://dx.doi. org/10.5101/nml.v3i1.p6-11

[37] X. G. Lin, Used for photovoltaic device of $\mathrm{ZnO}$ base type II heterogeneous structure design [D], Xiamen University, 2010.

[38] X. Q. Meng, H. W. Peng, Y. Q. Gai and J. B. Li, J. Phys. Chem. C 114, 1467 (2010). http://dx.doi.org/ 10.1021/jp909176p

[39] Z. H. Wang, Y. C. Fan and M. W. Zhao, J. Appl. Phys. 108, 123707 (2010). http://dx.doi.org/10.1063/1. 3504225

[40] A. Nduwimana, R. N. Musin, A. M. Smith and X. Q. Wang, Nano Lett. 8, 3341 (2008). http://dx.doi. org/10.1021/nl8017725

[41] Y. Tak, S. J. Hong, J. S. Lee, and K. Yong, J. Mater. Chem. 19, 5945 (2009). http://dx.doi.org/10.1039/ b904993b

[42] K. Wang, J. J. Chen, W. L. Zhou, Y. Zhang, Y. F. Yan, J. Pern and A. Mascarenhas, Adv. Mater. 20, 3248 (2008). http://dx.doi.org/10.1002/adma. 200800145

[43] P. T. Chou, C. Y. Chen, C. T.Cheng, S. C. Pu, K. C. Wu, Y. M. Cheng, C. W. Lai, Y. H. Chou, and H. T. Chiu, Chem. Phys. Chem. 7, 222 (2006). http://dx. doi.org/10.1002/cphc. 200500307

[44] W. F. Li, Y. G. Sun and J. L. Xu, Nano-Micro Lett. 4 (2), 98-102 (2012). http://dx.doi.org/10.3786/nml. v4i2.p98-102

[45] Y. Tak, H. Kim, D. Lee, and K. Yong, Chem. Commun., 4585 (2008). http://dx.doi.org/10.1039/ b810388g

[46] R. Tena-Zaera, A. Katty, S. Bastide, and C. LévyClément, Chem. Mater. 19, 1626 (2007). http://dx. doi.org/10.1021/cm062390f

[47] J. Bang, J. Park, J. H. Lee, N. Won, J. Nam, J. Lim, B. Y. Chang, H. J. Lee, B. Chon, J. Shin, J. B. Park, J. H. Choi, K. Cho, S. M. Park, T. Joo and S. Kim, Chem. Mater. 22, 233 (2010). http://dx.doi.org/10. $1021 / \mathrm{cm} 9027995$

[48] A Dinger, S Petillon, M Grün, M Hetterich and C Klingshirn, Semicond. Sci. Technol. 14, 595 (1999). http://dx.doi.org/10.1088/0268-1242/14/7/301

[49] D. J. Milliron, S. M. Hughes, Y. Cui, L. Manna, J. B. Li, L. W. Wang and A. P. Alivisatos, Nature 430, 190 (2004). http://dx.doi.org/10.1038/nature02695

[50] J. C. Ni, Z. M. Wu, X. G. Lin, J. J. Zheng, S. P. Li, J. Li and J. Y. Kang, J. Mater. Res. 27, 730 (2012). http://dx.doi.org/10.1557/jmr.2011.417

[51] Z. M. Wu, Y. Zhang, J. J. Zheng, X.G. Lin, X. H. Chen, B. W. Huang, H. Q. Wang, K. Huang, S. P. 
Li, and J. Y. Kang, J. Mater. Chem. 21, 6020 (2011). http://dx.doi.org/10.1039/c0jm03971c

[52] J. J. Zheng, Z. M. Wu, W. H. Yang, S. P. Li and J. Y. Kang, J. Mater. Res. 25, 1272 (2010). http://dx. doi.org/10.1557/JMR. 2010.0161

[53] S. Gubbala, V. Chakrapani, V. Kumar and M. K. Sunkara, Adv. Funct. Mater. 18, 2411 (2008). http:// dx.doi.org/10.1002/adfm. 200800099

[54] S. Cho, J. W. Jang, J. Kim, J. S. Lee, W. Choi, and K.H. Lee, Langmuir 27, 10243 (2011). http://dx.doi. org/10.1021/la201755w

[55] S. Cho, J. W. Jang, Sang-Hoon Lim, Hyun Joon Kang, Shi-Woo Rhee, Jae Sung Lee and Kun-Hong Lee, J. Mater. Chem. 21, 17816 (2011). http://dx.doi.org/ 10.1039/c1jm14014k

[56] J. Chung, J. Myoung, J. Oh, and S. Lim, J. Phys. Chem. Solids 73, 535 (2012). http://dx.doi.org/10. 1016/j.jpcs. 2011.12.001

[57] J. Chung, J. Myoung, J. Oh and S. Lim, J. Phys. Chem. C 114, 21360 (2010). http://dx.doi.org/10. 1021/jp109355h

[58] H. Y. Chao, S. H. You, J. Y. Lu, Y. H. Chang, C. T. Liang and C. T. Wu, Journal of Nanoscience and Nanotechnology 11, 2042 (2011). http://dx.doi.org/10. $1166 / j n n .2011 .3128$

[59] K. Wang, J. J. Chen, Z. M. Zeng, J. Tarr, W. L. Zhou, Y. Zhang, Y. F. Yan, C. S. Jiang, J. Pern, and A. Mascarenhas, Appl. Phys. Lett. 96, 123105 (2010). http: // dx. doi.org/10.1063/1.3367706

[60] Z. Y. Fan, H. Razavi, J. Do, A. Moriwaki, O. Ergen, Y. L. Chueh, Paul W. Leu, J. C. Ho, T. Takahashi, L. A. Reichertz, S. Neale, K. Yu, M. Wu, J. W. Ager and A. Javey, Nat. Mater. 8, 648 (2009). http://dx.doi. org/10.1038/nmat2493 